\title{
Women and Wealth: Financial
} Propinquity to Business Success

\author{
Nikunj Aggarwal ${ }^{1}$ and Harjit Singh ${ }^{2}$
}

\begin{abstract}
Around the globe, women's income and wealth are increasing as never before. Prevailing economic, demographic, and technological changes are growing women's financial strength and independence. Be it finance, marketing, supply chain or ICT based industry, women have made incredible strides, both at professional and social fronts, particularly in the two decades. Today they are better educated, well placed and have greater accountability in the corporate world and are frontrunners in many professions. Consequently, women, particularly in developing countries like India and China have become economic powerhouses. They not only significantly contribute to GDP but also are becoming a substantial untapped market for the wealth management industry. In this context, this study is an attempt to discuss the much talked about, but less understood, issue of women's wealth management in the Indian context. The study is intended to explore financial planning awareness among working women and their attitude towards wealth management. The findings will help wealth managers and financial planners to develop a deeper understanding of female investors' goals and priorities, investment patterns of the working women and to gain insight into gender specific investment behaviour of Indian investors.
\end{abstract}

JEL classification: D 30, D 31, D 33.

Keywords: Wealth Management, Women, India, Gender, Financial Literacy, Financial Security, Investment Planning, Financial Awareness.

\footnotetext{
${ }^{1}$ Research Scholar, Faculty of Management Studies, University of Delhi, India

${ }^{2}$ Associate Professor, Amity School of Business, Amity University, Uttar Pradesh, India
} 


\subsection{INTRODUCTION}

Global financial markets have developed substantially in the context of long-term reforms directed at increasing market efficiency and consumer choice, with consequential benefits for individuals and the wider economy. The financial services world, especially wealth management, has traditionally been very much a male domain. But the scenario is changing fast. The game is old, but the rules are new and still developing. Women are literate and entering into all the sectors of the economy. As per the Boston Consultancy Group (BCG) Report of 2018 on 'Wealth Management Experience for Women" reveals the fact that as wealth management clients, women are both significant and undervalued. They control a substantial segment of the world's wealth, yet more than half of the women thought that wealth managers could do a better job of meeting the needs of female clients - and nearly a quarter think that wealth managers could significantly improve how they serve women. India is not an exception. The extent to which Indian evidence justifies this perception is addressed in the research study.

\subsection{LITERATURE REVIEW}

Investment professionals who switch from managing institutional portfolios to managing individuals' portfolios quickly learn the peculiarities of private wealth management. Portfolio design and investment policy development are affected by individuals' views and circumstances with respect to (1) return and spending requirements, (2) risk,(3) taxation, (4) investment horizon, (5) liquidity needs, (6) legal structures and requirements, as well as (7)individual circumstances. Women wealth management encompasses both taxable investment management and personal financial planning concerns. Wealth management represents a specialization within investment management that addresses the particular concerns of high-net-worth individuals. Wealth management also represents an increase in professionalism and technical acumen over 1980s-era classical financial planning. The word "women wealth," although not strictly necessary, connotes the intensely personal and consultative relationship of private bankers - something private wealth managers aspire to have with their clients. Women wealth management, although centered on investment management, considers the complete financial picture of individuals and families and does so in a well-integrated fashion.

Brunel (2002) is the benchmark reference for women wealth management-surveying many of the topics we investigate in this literature review. Evensky (1997) provided a survey of wealth management from his financial planning perspective. Reichenstein and Jennings (2003) captured much of our thinking on wealth management. His three main observations are (1) managing the relationship and the transition from the current portfolio to the optimal portfolios important, (2) taxable investors should focus on wealth accumulation and asset location rather than periodic returns, and (3) individuals must focus on the total portfolio, not its components.

\section{Strategic Asset Allocation and Investment Policy}

Asset allocation for private wealth management differs from institutional investment asset allocation in a number of respects. The classic Markowitz mean-variance optimization must reflect after-tax values for both risk and return. There may be "legacy holdings" with a low tax basis. The diversification and return attributes of alternative investments, particularly hedge funds, must be balanced with their tax inefficiency. Individuals may hold stock 
options. A broad interpretation of asset allocation properly includes off-balance-sheet assets and liabilities, such as defined-benefit pensions or prospective college tuition payments. In an after-tax environment,the hurdles for market timing and tactical asset allocation, which were already high, are worse.

Bronson et al (2007) took a broad view of the process of setting investment policy and asset allocation specifically. Brunel (1999a) discussed the high costs for a taxable investor of panic-induced selling and thus underscores the importance of getting the asset mix right in the first place. Messmore (1995) demonstrated how volatility widens the spread between the arithmetic and geometric average return; although the message is not new, it is worth repeating. Jacob (1998) provides an interesting overview of the difference between traditional portfolio optimization and optimization for private wealth clients. Campbell (2004) and Wilcox, Horvitz, and di Bartolomeo (2006) considered both long-horizon and life-cycle investment perspectives for individuals making the asset allocation decision. Brunel (1999b), Corriero (2005), Milevsky (2004), and Terhaar, Staub, and Singer (2003) examined alternative assets in strategic asset allocation.

Milevsky (2004) found low correlations between returns on alternative assets and traditional asset classes are part of the case for such alternatives. Milevsky demonstrates that low correlation between a given asset class and the remainder of the portfolio increases the likelihood of breaching a given policy weight. Therefore, low-correlation, illiquid asset classes should receive smaller initial allocations than traditional mean-variance analysis suggests. The mathematical appendix uses continuous-time calculus to support the conclusion.

Terhaaret et al (2003) differs from a large body of literature on the appropriate allocation to nontraditional asset classes. The typical approach in the literature is to rely on historical, or history based, return patterns and mean-variance optimization. Instead, this study uses a factor model and simulation. The article is a general investment piece, not specialized for private wealth management. The authors' approach recommends a much smaller allocation to alternative assets than the typical approach used elsewhere in the literature.

\section{Portfolio Implementation}

After the strategic asset mix is decided, the work of the wealth manager is not done. The operational realities of private wealth management differ from those of institutional investment management. An institutional manager may apply a multimanager, or openarchitecture, approach, whereby he tries to select the best manager for each asset class. For example, he may select a large-capitalization value manager and a large cap growth manager among a stable of managers. A stock price increase might cause a stock to be sold by the value manager and bought by the growth manager, thus producing a tax liability. This example demonstrates one of the tax inefficiencies inherent in a multimanager approach. An alternative approach is a core-and-satellite approach, whereby the core equity portfolio consists of a broad-based (i.e., multi cap, multi style) equity portfolio that is managed tax efficiently. Additionally, specialist satellite managers might be selected to augment the core portfolio and provide size and style tilts to the overall portfolio. Therefore, tax-efficient management for the private wealth manager goes beyond the active-versus-passive debate. Insights from this debate are important when discussing the relative benefits of a core-andsatellite approach versus a broad multi manager approach. Studies by Brunel (2000a), Curtis 
(2006), Quisenberry (2003), and Rogers (2001) weighted the merits of each approach. The tax cost of rebalancing is another topic of significance to private wealth managers.

\section{Tax Management}

For many private wealth management clients, a substantial part of their financial portfolio will be held in taxable accounts. In taxable accounts, private wealth managers should be less concerned with pretax returns than with after-tax returns. Therefore, they must consider the tax costs of realizing capital gains and the benefits of allowing unrealized gains to grow tax deferred. In addition, they must consider the tax benefits of harvesting capital losses. Chincarini and Kim (2001), Horvitz and Wilcox (2003), and Stein and Narasimhan (1999), Davidson (1999) examined the tax management of fixed-income portfolios. Bergstresser and Poterba (2002) concluded that mutual fund inflows and outflows are better explained by funds' after-tax returns than their pretax returns. Constantinides' (2004) study was an early and important work emphasizing the tax timing option implicit in trading.

\section{Gender Difference and Behavioral Finance}

Alex Wang (2011) concluded that gender emerges as the most important factor that differentiates younger generations' investing behaviors in mutual funds. The findings point out challenges for younger women's wealth management, as they tend to exhibit fewer investing behaviors in mutual funds than their counterparts do. Consistent with previous research on wealth management among older generations, gender differences have significant implications for wealth advisors. As a result, wealth advisors should help younger women enhance their wealth management and financial future by facilitating their acquisition of necessary financial knowledge and experiences urged to and their involvement with their wealth management. Wealth advisors are also considering helping their clients manage their wealth by being aware of gender-predicted differences in client situations. Meenakshi Chaturvedi, Shruti Khare (2012) proclaimed that the age of investor cannot be taken to influence their level of awareness and it is very clear from the results that the gender of the investor has no effect or influence on his or her level of awareness about any investment channel. Badunenko, Barasinska and Schäfer (2010) suggest that women tend to be more cautious about investment decisions because- as a rule - they have less investment resources available than men at their disposal.

Collard (2009) has concluded that both men and women tend to be risk averse (women in particular), and seek to minimizes losses rather than maximize gains, even in relation to long term investments such a pension. Sapienza, Zingales and Maestripieri (2009) explored the biological explanation for this fact in a study which demonstrated that differences in testosterone levels influence relevant aspects of financial behaviour.Mittal M. and A. Dhade (2007) observed that risk-taking involves the selection of options that might result in negative outcomes. While the present is certain, the future is uncertain. Hence, all investment involves risk. Desigan et al. (2006) conducted a study on women investor's perception towards investment and found that women investor's basically are indecisive in investing in MFs due to various reasons like lack of knowledge about the investment protection and their various investment procedures, market fluctuations, various risks associated with investment, assessment of investment and redressal of grievances regarding their various investment related problems. 
Hira and Loibl (2006) examined gender differences between highly educated and highincome households in the USA and concluded that men were more likely than women to take above-average or substantial risk with their investments. Dohmen (2005) suggested that individual's risk attitude is also influenced by their parent's education, meaning that individuals whose parents are highly educated are less risk averse. Tippet and Leung (2001) have compared the demographic characteristics of "ethical" and conventional investors in Australia and have found a gender effect: ethical investors were more likely to be female rather than male. Barber and Odean (2001) observe that men tend to be more overconfident than women and, consequently, will trade more and perform worse than women. They analyzed the common stock investments of males and females and found that men trade 45 percent more than women and earn annual risk-adjusted net returns that are 1.4 percent less than those earned by women.

Olsen (2001) considers that risk perception is influenced by social and cultural factors such as trust, fairness and democratic values. Grable (2000) associates greater levels of education to higher levels of risk tolerance. Risk attitude has been associated with education. Morse (1998) suggests that the level of financial risk-taking of an individual is influenced by demographic factors (gender, age, education), socioeconomic (income, profession), and personality aspects. It has been suggested that the difference in risk attitudes of men and women in investment such as sensation-seeking and attitudes decisions are often related to risk perception rather than the reactions to a given level of risk. So, the factors which influence risk perception would play an important role in financial decisions.

Jianakopolos and Barnesek (1998) observed in their research that a higher percentage of women than men were unwilling to face any financial risks at all. According to Vanita (1988) men enjoy superior status in their households and they alone take most of the important decisions concerning family matters. Women's participation in gainful employment is bound to bring changes in their position in the family. Working women jointly or independently manage the family budget. According to the Wall Street Journal, women represent $40 \%$ of the world's labor force, and yet hold just $1 \%$ of the world's wealth. Women should feel empowered to have the confidence to make informed decisions in all aspects of their lives and the role their finances will play in supporting those values.

\section{Gap Analysis}

The review of literature suggests that significant research has been done on financial literacy, financial awareness and some of the aspects of investment decision making in India and abroad but very few studies took place around women empowerment involving demographic factors, socio-economic factors and behavioural aspects. The factors influencing financial literacy barring women empowerment are among some of the untouchable aspects with regard to women empowerment and sustainable development. The present study focusses on financial literacy among working women in India and also examines how well-equipped they are to make financial decisions. The research also concentrates on their sources, their knowledge and the challenges faced by them in financial matters.

\subsection{RESEACH METHODOLOGY}

The research methodology for the proposed study would involve five stages namely: exploratory research, sampling, development work, data collection and data analysis. A descriptive research design has been used to conduct a survey of 300 samples. The sampling 
method followed in this study is convenience sample method. Samples were taken from four major cities of Delhi NCR: Delhi, Noida, Gurugram and Faridabad. 300 working women were further classified as 100 private sector, 100 Public Sector and 100 Government sector employees. From each city, 25 Private sector, 25 Public sector and 25 Government sector employees were selected. Secondary data is collected from various books, Journals, thesis, periodicals, websites, and articles for the study.

\subsection{Research Method}

The present study is exploratory in nature and put efforts to understand the dynamics and issues related to women empowerment. The convenience sampling method is being adopted to collect information from working women. The primary data is collected through questionnaire distributed to working women while secondary data is collected from past studies, libraries, books, journals, thesis, periodicals, website and so on. Initially, a rough draft was prepared keeping in mind the objectives of the research. The final questionnaire was arrived at only after certain important changes were incorporated to develop a deep understanding of female investors' goals and priorities and to know gender specific investment behavior of Indian investors.

\subsection{Tools for Analysis}

Econometric such as percentage analysis, cross percentage analysis, Chi-Square Test and Kruskal Wallis test ${ }^{3}$ were applied to study the objectives of the proposed study. Microsoft Excel was used for the data entry stage. Later that data was exported to SPSS. Microsoft Excel was also used to find some descriptive analysis. Data collected on Likert Scale is an ordinal data. Normality of ordinal data could not check so for study incorporated nonparametric test. SPSS-20 version was used to perform various tests like Chi-Square, Kruskal Wallis Test, Factor analysis etc. To assess the financial literacy of the respondents, percentage analysis applied. To find the relationship between different demographic factors and financial literacy Chi-square test has been conducted. In order to measure level of awareness a three point scale is used where 1 indicates unaware, 2 indicates moderately aware and 3 indicates completely aware of the investment avenue. To find association between awareness level of respondents towards various investment avenues and different demographic variables, Kruskal Wallis Test has been used.

\subsection{Variables used in study}

Independent Variables used in study are socio economic and demographic variables (age, level of education and type of the job). Dependent variables are financial literacy and financial awareness.

\footnotetext{
${ }^{3}$ The Kruskal Wallis test is non-parametric, one-way method for testing whether samples originate from the same distribution. It is used for comparing two or more independent samples of equal or different sample sizes. It extends the Mann-Whitney U test, which is used for comparing only two groups. The parametric equivalent of the Kruskal-Wallis test is the one-way analysis of variance (ANOVA).
} 


\subsection{Objectives}

The primary objective of the study is to examine the perspectives of working women in India about their finances, financial decisions, and sources of information and support. This throws light on whether female investors in India are really financially savvy despite their professional and personal challenges. The sub-objectives of the study are: -

1. To check financial literacy among the working women of Delhi NCR.

2. To study the relationship between demographic and socio economic factors of investors and their financial literacy level.

3. To study the awareness of personal wealth management among the working women of Delhi NCR.

4. To assess the attitude towards Personal wealth management of the working women of Delhi NCR.

\subsection{Assessing Financial Literacy}

To assess the level of financial literacy, respondents were asked questions related to compounding of Interest Rate, Inflation, Diversifications, Risk- Return Relationship, concept of Time Value of Money and the relationship between interest rate and bond price etc. while to find the relationship between different demographic factors and financial literacy Chisquare test has been conducted. Different demographic factors which have been used in the study are age, education, job type etc.

\subsection{Hypothesis for Financial Literacy}

H0: There is no significant relationship between different demographic factors of the respondents and the financial literacy of the respondents.

H1: There is a significant relationship between different demographic factors of the respondents and financial literacy of the respondents.

Table 1: Financial Literacy of the Respondents

\begin{tabular}{|l|l|l|l|}
\hline \multicolumn{2}{|c|}{} & Frequency & Percentage \\
\hline \multirow{3}{*}{ Valid } & Financial Literate & 162 & 54 \\
\cline { 2 - 4 } & Financial Illiterate & 138 & 46 \\
\cline { 2 - 4 } & Total & 300 & 100 \\
\hline
\end{tabular}

Source: Compiled by Authors

It is revealed that most of the respondents have fair financial literacy. This shows that respondents are fairly learned and aware of financial terms, concepts and its working. But know less about the relationship between interest rate and bond price. They consider bonds as an investment which is long term oriented. It has been found that demographic variables like age, gender, education, income and work experience are related to financial literacy.

\section{Assessing Awareness of Financial Products}

In order to study the level of the financial awareness of the residents of Delhi NCR, respondents were asked to select their level of awareness concerning to various investment avenues like saving account, fixed deposit account, equity shares, public provident fund, derivatives, mutual funds, money market, tax saving schemes, non-conventional avenues. 
The level of awareness level was measured on 3 point scale where1 indicates unaware, 2 indicate moderately aware and3 indicate completely aware about investment avenue.

\section{Hypothesis for Financial Awareness}

H0: There is no significant relationship between different demographic factors of the respondents and financial awareness of the respondents.

H1: There is significant relationship between different demographic factors of the respondents and financial awareness of the respondents.

It is being observed that respondents are highly aware for Saving Bank Account, Life Insurance Policy, Post Office Schemes and Public Provident Fund. Lowest awareness is observed for Futures and Options, Money Market Instruments and Financial Derivatives. Low risk products are more popular among the respondents.

\section{Inferential Statistics Pertaining to Awareness of Different Investment Avenues}

To find association between Awareness level of respondents towards various investment avenues and different demographic variables, Kruskal Wallis Test has been used.

H0: There is no significant relationship between age of the respondents and financial awareness of the respondents.

H1: There is significant relationship between age of the respondents and financial awareness of the respondents. 
Table 2: The Mean Rank of Percentage of age of the respondents and awareness of different Investment

\begin{tabular}{|c|c|c|c|}
\hline & Age & No. of Respondents & Mean Rank \\
\hline \multirow[t]{4}{*}{ Saving Account } & $21-35$ & 103 & 152.50 \\
\hline & $36-50$ & 118 & 156.25 \\
\hline & 51-above & 129 & 128.24 \\
\hline & Total & 300 & \\
\hline \multirow{4}{*}{$\begin{array}{l}\text { Fixed } \\
\text { Account }\end{array}$} & $21-35$ & 103 & 156.23 \\
\hline & $36-50$ & 118 & 152.4 \\
\hline & 51-above & 129 & 118.3 \\
\hline & Total & 300 & \\
\hline \multirow[t]{4}{*}{ Equity Shares } & $21-35$ & 103 & 185.89 \\
\hline & $36-50$ & 118 & 123.25 \\
\hline & 51-above & 129 & 150.24 \\
\hline & Total & 300 & \\
\hline \multirow{4}{*}{$\begin{array}{l}\text { Public } \quad \text { Provident } \\
\text { Fund }\end{array}$} & $21-35$ & 103 & 156.25 \\
\hline & $36-50$ & 118 & 154.23 \\
\hline & 51-above & 129 & 104.25 \\
\hline & Total & 300 & \\
\hline \multirow{4}{*}{$\begin{array}{l}\text { Financial } \\
\text { Derivatives }\end{array}$} & $21-35$ & 103 & 172.24 \\
\hline & $36-50$ & 118 & 119.25 \\
\hline & 51-above & 129 & 183.21 \\
\hline & Total & 300 & \\
\hline \multirow[t]{4}{*}{ Mutual Funds } & $21-35$ & 103 & 143.28 \\
\hline & $36-50$ & 118 & 119.52 \\
\hline & 51-above & 129 & 119.01 \\
\hline & Total & 300 & \\
\hline \multirow[t]{4}{*}{ Money Market } & $21-35$ & 103 & 162.49 \\
\hline & $36-50$ & 118 & 158.27 \\
\hline & 51-above & 129 & 93.05 \\
\hline & Total & 300 & \\
\hline \multirow[t]{4}{*}{ Tax Saving Schemes } & $21-35$ & 103 & 174.21 \\
\hline & $36-50$ & 118 & 118.25 \\
\hline & 51-above & 129 & 134.43 \\
\hline & Total & 300 & \\
\hline \multirow{4}{*}{$\begin{array}{l}\text { Non-Conventional } \\
\text { Avenues }\end{array}$} & $21-35$ & 103 & 145.23 \\
\hline & $36-50$ & 118 & 168.57 \\
\hline & 51-above & 129 & 119.23 \\
\hline & Total & 300 & \\
\hline
\end{tabular}

Source: Primary Data 
Table 3: Showing the Test Statistics - Kruskal Wallis Test - Awareness of Different Investment Avenues among Age of the respondents

\begin{tabular}{|l|l|l|l|}
\hline Investment Avenues & Chi- Square & Degree of freedom & P value \\
\hline Saving Account & 13.023 & 2 & .003 \\
\hline Fixed Deposit Account & 33.45 & 2 & .000 \\
\hline Equity Shares & 68.35 & 2 & .000 \\
\hline Public Provident Fund & 86.12 & 2 & .000 \\
\hline Mutual Funds & 36.11 & 2 & .000 \\
\hline Money Market & 2.52 & 2 & .192 \\
\hline Tax Saving Schemes & 117.24 & 2 & .000 \\
\hline $\begin{array}{l}\text { Non-Conventional } \\
\text { Avenues }\end{array}$ & 12 & 2 & .004 \\
\hline
\end{tabular}

Source: Primary Data

Table 3 shows the calculated Chi-Square, degree of freedom, and p- value. P-Value is less than 0.05 for awareness regarding saving account, fixed deposits, equity shares, public provident fund mutual funds, tax saving schemes and Non- Conventional Avenues, so null hypothesis is rejected. P- Value is more than 0.05 for the money market. So, test statistics doesn't support us to reject the Null Hypothesis.

Hence we can conclude that for saving account, fixed deposits, equity shares, public provident fund mutual funds, tax saving schemes and non-conventional avenues, there is significant relationship between age of the respondents and financial awareness of the respondents. But for the money market, there is no significant difference in awareness regarding the money market and the age of the respondents.

Finding the relationship between education of the respondent and financial awareness of the respondent:

H0: There is no significant relationship between education of the respondents and financial awareness of the respondents.

H1: There is a significant relationship between education of the respondents and financial awareness of the respondents. 
Table 4: Mean Rank of Percentage of Education of the respondents and awareness of different Investment Avenues

\begin{tabular}{|c|c|c|c|}
\hline & Education & No. of Respondents & Mean Rank \\
\hline \multirow[t]{4}{*}{ Saving Account } & Graduate & 95 & 152.50 \\
\hline & Post Graduate & 175 & 147.55 \\
\hline & PhD. and others & 30 & 155.21 \\
\hline & Total & 300 & \\
\hline \multirow{4}{*}{$\begin{array}{ll}\text { Fixed } & \text { Deposit } \\
\text { Account } & \end{array}$} & Graduate & 95 & 163.21 \\
\hline & Post Graduate & 175 & 143.28 \\
\hline & PhD. and others & 30 & 119.01 \\
\hline & Total & 300 & \\
\hline \multirow[t]{4}{*}{ Equity Shares } & Graduate & 95 & 154.23 \\
\hline & Post Graduate & 175 & 123.25 \\
\hline & PhD. and others & 30 & 150.24 \\
\hline & Total & 300 & \\
\hline \multirow{4}{*}{$\begin{array}{l}\text { Public Provident } \\
\text { Fund }\end{array}$} & Graduate & 95 & 143.28 \\
\hline & Post Graduate & 175 & 154.76 \\
\hline & PhD. and others & 30 & 134.42 \\
\hline & Total & 300 & \\
\hline \multirow{4}{*}{$\begin{array}{l}\text { Financial } \\
\text { Derivatives }\end{array}$} & Graduate & 95 & 321.16 \\
\hline & Post Graduate & 175 & 157.21 \\
\hline & PhD. and others & 30 & 156.21 \\
\hline & Total & 300 & \\
\hline \multirow[t]{4}{*}{ Mutual Funds } & Graduate & 95 & 145.25 \\
\hline & Post Graduate & 175 & 160.21 \\
\hline & PhD. and others & 30 & 118.25 \\
\hline & Total & 300 & \\
\hline \multirow[t]{4}{*}{ Money Market } & Graduate & 95 & 134.43 \\
\hline & Post Graduate & 175 & 158.27 \\
\hline & PhD. and others & 30 & 93.05 \\
\hline & Total & 300 & \\
\hline \multirow[t]{4}{*}{ Tax Saving Schemes } & Graduate & 95 & 174.21 \\
\hline & Post Graduate & 175 & 162.49 \\
\hline & PhD. and others & 30 & 134.43 \\
\hline & Total & 300 & \\
\hline \multirow{4}{*}{$\begin{array}{l}\text { Non-Conventional } \\
\text { Avenues }\end{array}$} & Graduate & 95 & 104.21 \\
\hline & Post Graduate & 175 & 183.21 \\
\hline & PhD. and others & 30 & 147.55 \\
\hline & Total & 300 & \\
\hline
\end{tabular}

Source: Primary data 
Table 5: Showing Test Statistics - Kruskal Wallis Test - Awareness of Different Investment Avenues among education of the respondents

\begin{tabular}{|l|l|l|l|}
\hline Investment Avenues & Chi- Square & Degree of freedom & P value \\
\hline Saving Account & 3.154 & 2 & .217 \\
\hline Fixed Deposit Account & 11.087 & 2 & .000 \\
\hline Equity Shares & 19.87 & 2 & .006 \\
\hline Public Provident Fund & 18.25 & 2 & .002 \\
\hline Financial Derivatives & 10.531 & 2 & .002 \\
\hline Mutual Funds & 49.23 & 2 & .000 \\
\hline Money Market & 11.21 & 2 & .007 \\
\hline Tax Saving Schemes & 39.23 & 2 & .000 \\
\hline $\begin{array}{l}\text { Non-Conventional } \\
\text { Avenues }\end{array}$ & 41.78 & 2 & .000 \\
\hline
\end{tabular}

Source: Primary Data

Table 5 shows the calculated Chi-Square, degree of freedom, and p- value. P-Value is less than 0.05 for awareness regarding fixed deposit accounts, equity shares, public provident fund, financial derivatives, mutual funds, money market, tax saving schemes and NonConventional Avenues, so we reject the null hypothesis for these factors. P- Value is more than 0.05 for a savings account. So, test statistics doesn't support us to reject the Null Hypothesis.

Hence we can conclude that for fixed deposit accounts, equity shares, public provident fund mutual funds, money market, tax saving schemes and Non- Conventional Avenues, there is a significant relationship between education of the respondents and financial awareness of the respondents. But for saving account there is no significant relationship in Awareness regarding saving account and education of the respondents.

Finding relationship between the type of the job of the respondent and the financial awareness of the respondent:

H0: There is no significant relationship between the type of job held by the respondents and the financial awareness of the respondents.

H1: There is significant relationship between the type of job held by the respondents and the financial awareness of the respondents. 
Table 6: Mean Rank of Percentage of type of the job of the respondents and Awareness of different Investment Avenues

\begin{tabular}{|c|c|c|c|}
\hline & Type of job & No. of Respondents & Mean Rank \\
\hline \multirow[t]{4}{*}{ Saving Account } & Public sector & 100 & 143.25 \\
\hline & Private sector & 100 & 156.75 \\
\hline & Government employees & 100 & 154.35 \\
\hline & Total & 300 & \\
\hline \multirow{4}{*}{$\begin{array}{l}\text { Fixed } \\
\text { Account }\end{array}$} & Public sector & 100 & 126.28 \\
\hline & Private sector & 100 & 157.18 \\
\hline & Government employees & 100 & 167.28 \\
\hline & Total & 300 & \\
\hline \multirow[t]{4}{*}{ Equity Shares } & Public sector & 100 & 154.51 \\
\hline & Private sector & 100 & 147.27 \\
\hline & Government employees & 100 & 149.50 \\
\hline & Total & 300 & \\
\hline \multirow{4}{*}{$\begin{array}{l}\text { Public } \quad \text { Provident } \\
\text { Fund }\end{array}$} & Public sector & 100 & 161.24 \\
\hline & Private sector & 100 & 142.54 \\
\hline & Government employees & 100 & 146.00 \\
\hline & Total & 300 & \\
\hline \multirow{4}{*}{$\begin{array}{l}\text { Financial } \\
\text { Derivatives }\end{array}$} & Public sector & 100 & 123.50 \\
\hline & Private sector & 100 & 153.45 \\
\hline & Government employees & 100 & 172.00 \\
\hline & Total & 300 & \\
\hline \multirow{4}{*}{ Mutual Funds } & Public sector & 100 & 150.85 \\
\hline & Private sector & 100 & 154.23 \\
\hline & Government employees & 100 & 142.65 \\
\hline & Total & 300 & \\
\hline \multirow[t]{4}{*}{ Money Market } & Public sector & 100 & 145.25 \\
\hline & Private sector & 100 & 158.27 \\
\hline & Government employees & 100 & 146.00 \\
\hline & Total & 300 & \\
\hline \multirow[t]{4}{*}{ Tax Saving Schemes } & Public sector & 100 & 156.21 \\
\hline & Private sector & 100 & 142.35 \\
\hline & Government employees & 100 & 149.5 \\
\hline & Total & 300 & \\
\hline \multirow{4}{*}{$\begin{array}{l}\text { Non-Conventional } \\
\text { Avenues }\end{array}$} & Public sector & 100 & 119.25 \\
\hline & Private sector & 100 & 123.25 \\
\hline & Government employees & 100 & 134.42 \\
\hline & Total & 300 & \\
\hline
\end{tabular}

Source: Primary Data 
Table 7: Showing Test Statistics - Kruskal Wallis Test - Awareness of Different Investment Avenues among different type of the job of the respondents

\begin{tabular}{|l|l|l|l|}
\hline Investment Avenues & Chi-Square & Degree of freedom & P-value \\
\hline Saving Account & 2.356 & 2 & .240 \\
\hline Fixed Deposit Account & 36.34 & 2 & .000 \\
\hline Equity Shares & 3.34 & 2 & .490 \\
\hline Public Provident Fund & 20.15 & 2 & .002 \\
\hline Financial Derivatives & 7.22 & 2 & .000 \\
\hline Mutual Funds & 43.34 & 2 & .000 \\
\hline Money Market & 11.34 & 2 & .007 \\
\hline Tax Saving Schemes & 26.45 & 2 & .000 \\
\hline $\begin{array}{l}\text { Non-Conventional } \\
\text { Avenues }\end{array}$ & 46.44 & 2 & .000 \\
\hline
\end{tabular}

Source: Primary data

Table 7 shows the calculated Chi-Square, degree of freedom, and p- value. P-Value is less than 0.05 for awareness regarding fixed deposit accounts, public provident fund, financial derivatives, mutual funds, money market, tax saving schemes and Non- Conventional Avenues, so we reject the null hypothesis for these factors. P- Value is more than 0.05 for saving account and equity shares. So, test statistics doesn't support us to reject the Null Hypothesis.

Hence we can conclude that for fixed deposit accounts, public provident fund, financial derivatives, mutual funds, money market, tax saving schemes and Non- Conventional Avenues, there is a significant relationship between type of the job of the respondents and financial awareness of the respondents. But for saving account and equity shares there is no significant relationship in Awareness regarding saving account and equity shares and type of the job of the respondents.

\subsection{FINDINGS}

\section{Financial Literacy among Working Women}

1. $76 \%$ of the respondents know the concept of compounding interest rates. Only $24 \%$ of the respondents have failed to give the correct answer.

2. $73 \%$ of the respondents have a basic idea regarding the impact of inflation on purchasing power. $27 \%$ failed to give correct answer.

3. $66 \%$ of the respondents possess a fair knowledge of the time value of money. $34 \%$ of the respondents failed to give a correct answer for the same.

4. $70 \%$ of the respondents have a fair idea related to concept of diversification. $30 \%$ of the respondents did not have a fair knowledge of diversification.

5. $82 \%$ of the respondents know that risk and return go parallel to each other. $18 \%$ of the respondents failed to give the correct answer for the same.

6. Only $45 \%$ of the respondents are aware of the relationship between the rate of interest and price of the bond. 55\% of the respondents gave incorrect answer about the relationship between rate of interest and price of the bond. 
7. It has been revealed that $54 \%$ of the respondents are financially literate and $46 \%$ of them are financially illiterate.

8. $44 \%$ of the respondents have a reasonable awareness of financial products and returns generated by them. $56 \%$ of the respondents were not aware of the same.

\section{Financial Awareness}

1. $72 \%$ of the respondents are fully aware of savings accounts. $18 \%$ of the respondents are fairly aware regarding savings accounts and only $10 \%$ of the respondents are not aware of savings accounts.

2. $75 \%$ of the respondents are fully aware about fixed deposits. $15 \%$ of the respondents are fairly aware regarding fixed deposits and the remaining $10 \%$ of the respondents are not aware about fixed deposits.

3. $40 \%$ of the respondents are fully aware about the equity shares. $20 \%$ of the respondents are fairly aware regarding the equity shares and remaining $40 \%$ of the respondents are not aware about equity shares.

4. $80 \%$ of the respondents are fully aware about the Public Provident Fund. $10 \%$ of the respondents are fairly aware regarding the Public Provident Fund and remaining $10 \%$ of the respondents are not aware about Public Provident Fund.

5. $15 \%$ of the respondents are fully aware about the derivatives. $20 \%$ of the respondents are fairly aware regarding the derivatives and the remaining $70 \%$ of the respondents are not aware about derivatives.

6. $65 \%$ of the respondents are fully aware about the mutual funds. $20 \%$ of the respondents are fairly aware regarding the mutual funds and the remaining $15 \%$ of the respondents are not aware about mutual funds.

7. $12 \%$ of the respondents are fully aware about the money market. $20 \%$ of the respondents are fairly aware regarding the money market and remaining $68 \%$ of the respondents are not aware about the money market.

8. $62 \%$ of the respondents are completely aware about tax saving schemes. $18 \%$ of the respondents are moderately aware regarding the tax saving schemes and remaining 20 $\%$ of the respondents are not aware about tax saving schemes.

9. There was little awareness regarding non-conventional investment avenues among the respondents.

Thus, Respondents possessed fair awareness pertaining to traditional Investment Products. These findings are in line with past research done in the area of personal financial planning.

\subsection{Managerial Implications of this study}

There are few studies done in the area of comprehensive Personal Financial Planning in India and especially in Delhi and NCR. This study will help individuals to better understand almost all of the processes and components of wealth management and personal financial planning. Apart from this, the study will render financial institutions, financial planners, academicians, and investment advisors better able to understand the attitudes of their customers and enable them help customers in a better manner. The study has created a base for a future more detailed study to be done in the area of wealth management. 


\subsection{Future Scope of Study}

The study is limited to 300 working women from Delhi NCR; further studies can be extended towards other states too. Further research can be carried out on businessmen and professionals also. The present study has focused on awareness and attitude as independent components. Further model showing linkages between Financial Awareness, Attitude, Behaviour and Financial Well-being can be established. The major attributes on which data is collected are age, level of education and type of job. But there are other socio demographic factors like marital status, family income and location of the job etc. which could have a significant effect on the financial awareness and attitude of respondents. The review of literature suggested that the various studies focussed on demographic factors, socio-economic factors and behavioural factors separately. The factors influencing financial literacy can be considered together to find which among the factors is having a significant influence.

\subsection{CONCLUSION}

In developing countries like India and China, the wealth management industry has, for decades, been largely about catering to one specific gender of individual: male, most likely somewhere in their thirties to sixties and with traditional family needs. The notion that a man would manage the finances for the household while the spouse will take care of domestic liabilities has changed. Today many women are equally participating in the earnings of a family. In some families and professions, they are even better paid than their male spouses. The study revealed that most of the respondents are not only financial literate but aware of the significance of prevailing financial instruments. They comprehend the importance of a balanced financial plan and admit that they require an expert to help them in drafting a sound financial plan. Overall, the study has crafted a base for the future detailed research to be done in the field of women wealth management especially from a South Asian aspect.

\section{REFERENCES}

Badunenko, O., Barasinska,N. \& Schäfer, D., 2009. Investments: Women are more cautious than men because they have less financial resources at their disposal. DIW Berlin Weekly Report.

Barber, B.M. ,\& Odean, T. (2001). Boys will be boys: gender, overconfidence, and common stock investment. The Quarterly Journal of Economics, 116(1), 261-92. https://doi.org/10.1162/003355301556400

Bergstresser, D., \& Poterba, J.M. (2002). Do After-Tax Returns Affect Mutual Fund Inflows? Journal of Financial Economics, 63(3), 381-414. https://doi.org/10.1016/S0304-405X(02)00066-1

Bronson, J. W., Scanlan, M. H. \& Squires, J. R. (2007). Managing Individual Investor Portfolios. In Managing Investment Portfolios: A Dynamic Process. Edited by John L. Maginn, Donald L. Tuttle, Jerald E.Pinto, and Dennis W. McLeavey. 3rd ed. Hoboken, NJ: John Wiley \& Sons.

Brunel, J. L. (1999b). The Role of Alternative Assets in Tax-Efficient Portfolio Construction. Journal of Private Portfolio Management, 2(1), 9-25.

https://doi.org/10.3905/jwm.1999.320346 
Brunel, J. L. (2000b). An Approach to After-Tax Performance Benchmarking. Journal of Private $\quad$ Portfolio $\quad$ Management, https://doi.org/10.3905/jwm.2000.320339

Brunel, J. L. (2002). Integrated Wealth Management: The New Direction for Portfolio Managers. London: Euromoney Books.

Campbell, J. Y. (2004). Measuring the Risks of Strategic Tilts for Long-Term Investors. The New World of Pension Fund Management. Edited by Rodney N. Sullivan, CFA. Charlottesville, VA: CFA Institute. https://doi.org/10.2469/cp.v2004.n6.3437

Chaturvedi, M., \& Khare, S. (2012). Study of saving pattern and investment preferences of individual household in India. International Journal of Research in Commerce \& Management, 3(5), 115-120.

Corriero, T. (2005). The Unique Tax Advantages of a Timber Investment. Journal of Wealth Management, 8(1), 58-62. https://doi.org/10.3905/jwm.2005.502668

Davidson, R. B. (1999). The Value of Tax Management for Bond Portfolios. Journal of Private Portfolio Management, 49-58. https://doi.org/10.3905/jwm.1999.320344

Desigan, C. G., Kalaiselvi, S., Anusuya, L. (2006). Women Investor's Perception towards Investment: An empirical Study. Indian Journal of Marketing. Retrieved from: http://www. google.com. (accessed on 22nd May 2010).

Grable, J. E. (2000). Financial risk tolerance and additional factors that affect risk taking in everyday money matters. Journal of Business and Psychology, 14(4), 625-630. https://doi.org/10.1023/A:1022994314982

Hira, T. K., \& Loibl, C. (2008). Gender differences in investment behavior. In J. J. Xiao (Ed.), Handbook of Consumer Finance Research. New York: Springer, 253-270. https://doi.org/10.1007/978-0-387-75734-6_15

Jacob, N. L. (1998). After-Tax Asset Allocation and the Diversification of Concentrated Low Cost-Basis Holdings: A Case Study. Journal of Private Portfolio Management, 1(1), 55-66. https://doi.org/10.3905/jwm.1998.409791

Kousalya, P. R., \& Gurusamy, P. (2012), Women Investors' Perception towards Investments. International Journal of Scientific Research, 1(6), 80-81. https://doi.org/10.15373/22778179/NOV2012/30

Milevsky, M. A. (2004). Illiquid Asset Allocation and Policy Weights: How Far Can They Deviate? Journal of Wealth Management, 7(3), 27-34. https://doi.org/10.3905/jwm.2004.450957

Mittal, M., \& Dhade, A. (2007). Gender Difference in Investment Risk-Taking: An Empirical Study. ICFAI Journal of Behavioural Finance, 4(1), 32-42.

Morse, C. (1998). Risk Taking in Personal Investments. Journal of Business and Psychology, 13 (2), 281-288. https://doi.org/10.1023/A:1022915224863

Platow, F. (2012). Gender \& Finance: financial profile of continuing education students according to gender. Christiane Koncilja-Brum Bern University of Applied Sciences, Business Division September 2012.

Reichenstein, W., \& Jennings, W. W. (2003). Integrating Investments and the Tax Code. New York: Wiley. 
Sapienza, P., Zingales, L. \& Maestripieri, D. (2009). Gender differences in financial risk aversion and career choices are affected by testosterone. Proceedings of the National Academy of Sciences.

Online: http://www.pnas.org/cgi/doi/10.1073/pnas.0907352106 (21.06.2012)Online:http://www.diw.de/documents/publikationen/73/diw_01.c.34535 4.de/diw_wr_2010-01.pdf (06.12.2011) https://doi.org/10.1073/pnas.0907352106

Singer. (2003). Appropriate Policy Allocation for Alternative Investments. Journal of Portfolio Management, 29(3), 101-110. https://doi.org/10.3905/jpm.2003.319888

Tippet, J. \& Leung, P. (2001). Defining Ethical Investment and its Demography in Australia. Australian Accounting Review, 11(3), 44-55. https://doi.org/10.1111/j.1835-2561.2002.tb00389.x

Wang, A. (2011). Younger Generations’ Investing Behaviors in Mutual Funds: Does Gender Matter? The Journal of Wealth Management, 13(4), 13-23. https://doi.org/10.3905/jwm.2011.13.4.013

Wilcox, J., Jeffrey E. H., \& Bartolomeo, D (2006). Life-Cycle Investing. Chapter 3 in Investment Management for Private Taxable Investors. Charlottesville, VA: Research Foundation of CFA Institute. 


\section{Annexure}

Exhibit 1: Difference between Public, Private and Government Sector

\begin{tabular}{|c|c|}
\hline Public Sector & $\begin{array}{l}\text { Public Sector refers to: } \\
\text { (a) Companies which are not private; } \\
\text { (b) have a minimum paid-up share capital, as may be prescribed. } \\
\text { Example: SBI, Indian Railways. }\end{array}$ \\
\hline Private Sector & $\begin{array}{l}\text { Private sector refers to: } \\
\text { - organizations that are not government owned, and } \\
\text { - the goods and services provided by organizations outside of the } \\
\text { government. } \\
\text { Example: Tata, Birla, Adani, Reliance. }\end{array}$ \\
\hline Government Sector & $\begin{array}{l}\text { Government Sector refers to: } \\
\text { Companies or organisations in which at least } 51 \% \text { of the paid up } \\
\text { share capital is held by the central or the state governments or partly } \\
\text { by both central and state government. } \\
\text { Example: SAIL, STC, ONGC. }\end{array}$ \\
\hline
\end{tabular}

